\title{
Strategi Humas Kementerian Koperasi dan Usaha Kecil dan Menengah Dalam Pengelolaan Jejaring Sosial
}

\author{
Mohammad Ribhul Azeem, Ahmad Toni \\ Public Relations FIKOM Universitas Budi Luhur \\ Jl. Ciledug Raya, RT.10/RW.2, Petukangan Utara, Pesanggrahan, Kota Jakarta Selatan, Daerah \\ Khusus Ibukota Jakarta 12260 \\ mohammadribhulazeem7@gmail.com,ahmad.toni@budiluhur.ac.id
}

\begin{abstract}
One Way Communication occurring at an institution the government should be changed into two way communication through media. Cooperative and Small Medium Enterprises Ministry Republic of Indonesia use social media as a means of the spread of information to interested parties. This research using the Media Richness Theory and uses Qualitative Case Study method by lifting cases of management media network happening in the society in the Division of Public Relations Cooperative and Small Medium Enterprises Republics Indonesia that has not yet been optimized. The research also use constructivism who regards paradigm of the solution of the problems faced by a solution .These are data to research for participating states in the form of observation internships and also with interviews with key informants, which are then data was compared with each other using a source of triangulation.The result of this research shows the important things can support of the effectiveness of the social media optimizations at Cooperative Small Medium Enterprises Ministry Republic of Indonesia such as management of information signs, feedback, focus development and language use.
\end{abstract}

Keywords: cooperative small medium enterprises ministry republic of indonesia. Public relations, social media,

\begin{abstract}
Abstrak
Komunikasi satu arah yang terjadi pada institusi pemerintah harus diubah menjadi komunikasi dua arah melalui media. Kementerian Koperasi dan UKM Republik Indonesia menggunakan media sosial sebagai sarana penyebaran informasi kepada pihak yang berkepentingan. Penelitian ini menggunakan teori kekayaan media dan menggunakan metode penelitian studi kasus kualitatif dengan mengangkat kasus berupa pengelolaan jejaring media sosial yang terjadi di Divisi Hubungan Masyarakat Kementerian Koperasi dan UKM Republik Indonesia. Penelitian ini juga menggunakan paradigma konstruktivisme. Pada penelitian ini data didapatkan melalui observasi partisipan berupa kegiatan magang dan wawancara dengan key informant, kemudian data tersebut dibandingkan satu sama lain menggunakan triangulasi sumber. Hasil yang didapat dalam penelitian ini menggambarkan bahwa pentingnya beberapa aspek yang mampu meningkatkan pengelolaan jejaring media sosial di Kementerian Koperasi dan UKM Republik Indonesia yang baik seperti pengelolaan tanda informasi, umpan balik, pengembangan fokus dan juga pemanfaatan bahasa.
\end{abstract}

Kata Kunci: kementerian koperasi dan UKM Republik Indonesia. media sosial, public relations 


\section{Pendahuluan}

Carlina \& Paramita (2017) menyebutkan bahwa majunya perkembangan zaman dan adanya perkembangan teknologi menyebabkan manusia menjadi mudah untuk melakukan komunikasi. Perkembangan zaman ini tentunya membawa dampak positif dan dampak negatif. Dampak positifnya manusia dapat menerima informasi dan menyampaikan informasi dengan mudah dan cepat. Dampak negatif dari adanya perkembangan zaman ini, muncul tantangantantangan baru bagi seorang Public Relations (PR) atau Humas. Penyebaran infomasi bisa secara luas dan cepat karena adanya internet, isu negatif tentang sebuah perusahaanpun bisa menyebar secara luas dan cepat. Kalangan instansi pemerintahan seharusnya menerapkan penggunaan media sosial untuk mendukung segala kinerja instansi pemerintahan tersebut. Penggunaan media sosial disini tidak hanya dikhususkan untuk instansi pemerintahan pusat yang berada di pusat ibukota negara saja, melainkan penggunaan media sosial ini seharusnya pula diterapkan oleh seluruh instansi pemerintahan, baik pemerintahan pusat maupun daerah.

Sejalan dengan hal tersebut Menteri Komunikasi dan Informatika Rudiantara mengajak seluruh kepala dinas komunikasi dan informatika, hubungan masyarakat dan pegawai pemerintah di daerah aktif menggunakan media sosial sebagai sarana komunikasi pemerintah dengan masyarakat. "Era komunikasi saat ini sudah berubah. Secara jumlah media sosial ini penggunanya banyak dan sudah digunakan sebagai jalur untuk berkomunikasi," tuturnya dalam Government Public Relations (GPR) Sharing mengenai Komunikasi Pemerintah di Era Digital, di Surabaya, Jawa Timur, Rabu (24/05/2017). Menteri Rudiantara memaparkan perubahan cara komunikasi pemerintah. Menurutnya, pemerintah daerah atau pusat dulu berkomunikasi satu arah. Tapi saat ini tidak bisa lagi, harus berubah. Oleh karena itu, akun media sosial yang dikelola oleh pemerintah provinsi, kabupaten dan kota agar dapat dijadikan kanal komunikasi. Selain pengelolaan kanal komunikasi, Menteri Rudiantara juga menekankan pengelolaan konten yang baik. Konten harus dikemas dengan baik melalui penyusunan agenda setting dan dapat digunakan untuk melawan hoaks.

Kementerian Koperasi dan UKM Republik Indonesia dalam menjalankan sebuah kewajibannya yang secara khusus menangani sektor koperasi dan UKM di seluruh Indonesia harus mampu menjamah pihak-pihak yang berkepentingan dalam jalannya kewajiban tersebut. Seperti yang telah dijelaskan diatas, bahwa media sosial menjadi penting untuk menjamah semua pihak yang memiliki kepentingan tersebut karena sifat dari media sosial yang luas dan mampu membuat koneksi antara satu pihak dengan pihak lain secara cepat. Kementerian Koperasi dan UKM Republik Indonesia, melalui Divisi Hubungan Masyarakat yang ada di dalam kementerian hendaknya sudah mampu mengaplikasikan media sosial di dalam menjalankan semua aktivitas kementeriannya. Dewasa ini dengan arus globalisasi yang semakin maju menjadi pendorong utama bagi semua instansi pemerintah untuk menggunakan media sosial, termasuk juga Kementerian Koperasi dan UKM Republik Indonesia, dengan demikian maka kegiatannya akan lebih mudah terlaksana dan dapat menjangkau publik lebih luas. 
Peran Divisi Hubungan Masyarakat Kementerian Koperasi dan UKM Republik Indonesia menjadi sangat penting bilamana penggunaan media sosial di dalam kehidupan Kementerian Koperasi dan UKM Republik Indonesia benarbenar dijalankan dengan baik, karena secara tugas dan fungsi dalam kaitannya dengan media sosial Divisi Hubungan Masyarakat-lah yang sangat berhak dalam mengurusi kegiatan tersebut, dimana pada prosesnya kegiatan penggunaan media sosial yang dikelola oleh Divisi Hubungan Masyarakat Kementerian Koperasi dan UKM Republik Indonesia harus mampu menjamah semua pihak-pihak yang memiliki kepentingan dengan Kementerian Koperasi dan UKM Republik Indonesia mulai dari yang ada di ibu kota hingga yang berada di pelosok-pelosok Indonesia.

Sejalan dengan kewajibannya dalam mengelola media masa bagi Divisi Hubungan Masyarakat Kementerian Koperasi dan UKM Republik Indonesia, Penulis berasumsi bahwa kegiatan penggunaan media sosial yang dilakukan oleh Divisi Hubungan Masyarakat Kementerian Koperasi dan UKM Republik Indonesia belum sepenuhnya dijalankan dengan baik dan benar, hal tersebut dilatarbelakangi bahwa informasi yang disebar oleh Divisi Hubungan Masyarakat Kementerian Koperasi dan UKM Republik Indonesia belum sepenuhnya dapat diterima oleh pihak-pihak yang berkaitan dengan Kementerian Koperasi dan UKM Republik Indonesia. Peraturan Menteri Komunikasi dan Informatika yang menyebutkan bahwa sistem komunikasi satu arah yang sudah terjadi dalam kehidupan sebuah institusi yang ada di Indonesia harus diubah menjadi komunikasi dua arah yang salah satunya menggunakan komunikasi dengan media sosial. Oleh karenanya, maka kehidupan komunikasi yang ada di dalam sektor institusi pemerintah harus dioptimalkan dalam penggunaannya terhadap media sosial.

Kementerian Koperasi dan UKM Republik Indonesia melakukan kegiatan tersebut yakni menggunakan media sosial dalam rangka mengemban tugasnya menyampaikan informasi keseluruh pihak yang memiliki kepentingan terhadap kementerian. Oleh karena itu Peneliti merumuskan masalah atas penelitian ini adalah, bagaimana strategi hubungan masyarakat Kemeterian Koperasi dan UKM Republik Indonesia dalam mengelola jejaring media sosial?

\section{Media Sosial}

Penggunaan media sosial di Kementerian Koperasi dan UKM Republik Indonesia menjadi hal yang penting bagi kelancaran arus informasi baik yang sifatnya informasi internal maupun eksternal. Yanti Herlanti (2004) menjelaskan bahwa Media sosial adalah media online yang memungkinkan bagi pengguna untuk berpartisipasi, berbagi dan menciptakan isi.

Pada dasarnya media sosial merupakan perkembangan mutakhir dari teknologi-teknologi web baru berbasis internet, yang memudahkan semua orang untuk berkomunikasi, berpartisipasi, saling berbagi dan membentuk sebuah jaringan secara online, sehingga dapat menyebarluaskan konten mereka sendiri. Post di Blog, Twit atau Video di Youtube dapat diproduksi dan dapat dilihat secara langsung oleh jutaan orang secara gratis. (Zarella, 2010). Media sosial adalah 
merupakan inovasi yang relatif terus berkembang, dan pemasaran media sosial merupakan industri yang relatif terus berkembang dinamis (Stelzner, 2016).

\section{Humas}

The Public Relations of America menyebutkan bahwa Humas adalah usaha organisasi untuk memperoleh kerjasama dari sekelompok orang. Humas membantu organisasi berinteraksi secara efektif dan berkomunikasi dengan publik utama. (Henny Kustini, 2017).

Suprawoto (2018) menjelaskan bahwa humas menurut F. Rachmadi, lebih menekankan pada esensi public relations, yaitu delebrate, planned, and sustained effort to establish and maintain mutual understanding between and organization and its public. Dari batasan tersebut F.Rachmadi tampak tidak jauh berbeda dengan SK Bonar, bahwa humas adalah usaha yang sengaja dan terus menerus dalam merencanakan untuk menjaga keberadaan dan memelihara hubungan yang saling pengertian antara organisasi dengan publik. Humas juga bisa diartikan sebagai sesuatu yang terdiri dari semua bentuk komunikasi berencana baik ke dalam maupun keluar yang bertujuan untuk mendapatkan citra positif dan dukungan dari publiknya.

Di dalam struktur Kementerian Koperasi dan UKM Republik Indonesia, Humas memiliki peranan penting sebagai jembatan informasi baik antar sesama internal Kementerian Koperasi dan UKM Republik Indonesia ataupun dari Kementerian Koperasi dan UKM Republik Indonesia kepada pihak luar. Humas dalam hal ini dipahami dalam konteks fungsi bukan dalam konteks divisi. Dalam konteks fungsi dalam organisasi, humas berdasar penelitian yang pernah dilakukan oleh Fraser P Seitel pada tahun 2001 dalam The Practice of Public Relation diberi label beragam antara lain : corporate communication, communication, public affair, advertising/ public relations, corporate relations dan public information.

\section{Strategi Humas}

Ruth Yearley, Planning Director dari Biro Konsultan Public Relations Ketchum London dalam Konferensi Chartered of Public Relations (CIPR) "Perfecting PR Strategy" di London pada tahun 2007 mengatakan :

"Kami melihat strategi sebagai sebuah penjelasan intelektual yang membantu tim dan semua orang yang terlibat dalam program public relations mengerti apa yang harus mereka capai dan bagaimana mereka akan mencapainya. Strategi merupakan pijakan bagi seluruh program dan tempat untuk selalu kembali untuk melihat bahwa kita berada pada jalur yang benar dan mengerti mengapa kita melakukan apa yang kita lakukan (Prayudi, 2012).

Menurut Ahmad S. Adnanputra, Presiden Institut Bisnis dan Manajemen Jayakarta, strategi humas adalah alternatif optional yang dipilih untuk ditempuh guna menapai tujuan PR dalam kerangka suatu rencana public relations (public relations plan) (Ruslan, 2016). Hubungan Masyarakat atau Humas yang baik atau bisa dikatakan kompeten adalah Humas yang mampu melakukan sebuah strategi 
yang baik, artinya strategi Humas adalah strategi yang harus memadai untuk berkomunikasi dengan berbagai mcam pihak yang berkepentingan tentang alasanalasan pergeseran dan dampaknya terhadap misi dan prioritas organisasi. Disamping itu, Humas juga memiliki strategi yang penting berkaitan dengan kehidupan stakeholders yakni Humas harus mampu menjalankan sebuah strategi yang mampu membangun strategi penyampaian pesan yang baik dan efektif kepada stakeholders internal maupun eksternal.

Peranan public relation dalam membangun citra positif dapat terlaksana dengan adanya strategi yang terencana dan matang. Strategi public relation atau yang lebih dikenal dengan bauran 4 menurut Ruslan (dalam Firsan, 2009) dapat disimpulkan sebagai berikut: a) Publications. Setiap fungsi dan tugas public relation adalah menyelenggarakan publikasi atau menyebarluaskan informasi. b) Kegiatan. Merancang sebuah Kegiatan yang bertujuan untuk memperkenalkan produk dan layanan perusahaan, mendekatkan diri ke publik dan lebih jauh lagi dapat mempengaruhi opini publik. c) News (Menciptakan Berita). Berupaya menciptakan berita melalui pres relase, news letter, bulletin, dll. Untuk itulah seorang public relation harus mempunyai kemampuan menulis dan menciptakan publisitas. d) Community Involvement (Kepedulian Pada Komunitas). Keterlibatan tugas sehari-hari seorang public relation adalah mengadakan kontak sosial dengan kelompok masyarakat tertentu guna menjaga hubungan baik (community relation dan humanity relation) dengan pihak organisasi atau lembaga yang diwakili. e) Lobbying and Negotiations (Melobi dan Bernegosiasi) Keterampilan untuk melobi melalui pendekatan pribadi dan kemampuan bernegosiasi, sangat diperlukan bagi seorang public relation. f) Social Responsibility (tanggung jawab sosial). Memiliki tanggung jawab sosial dalam aktivitas public relation menunjukkan bahwa perusahaan memiliki kepedulian terhadap masyarakat. Hal ini akan meningkatkan citra perusahaan di mata publik.

\section{Kekayaan Media}

Teori ini (Media Richness Theory) diutarakan oleh Daft \& Lengel (1984). Teori ini beranggapan manusia ingin mengatasi kesamaran dan ketidakpastian maklumat dalam organisasi. Disamping itu teori ini turut beranggapan ada pelbagai media yang biasa digunakan dalam organisasi yang mampu memberikan kesan yang lebih baik bagi suatu tugasan berbanding dengan media lain.

Teori kesempurnaan media menyatakan bahwa semua media memiliki kemampuan yang bervariasi untuk memungkinkan pengguna berkomunikasi dan mengubah pemahaman. Tingkat kemampuan ini dikenal sebagai 'kesempurnaan' media. MRT menempatkan semua media pada skala berkesinambungan berdasarkan kemampuan mereka untuk mengkomunikasikan pesan kompleks. Media yang dapat mengatasi perbedaan kerangka acuan referensi dengan efisien dan mengklarifikasi isu-isu yang ambigu dianggap lebih sempurna dibandingkan media komunikasi yang membutuhkan waktu lebih lama untuk menyampaikan pemahaman.

Alasan utama dalam memilih media komunikasi untuk pesan tertentu adalah untuk mengurangi ketidakjelasan pesan ataupun penafsiran pesan yang salah. Jika pesan kurang tegas, maka pesannya akan menjadi ambigu dan sulit 
dimengerti oleh penerima pesan. Semakin tidak jelas sebuah pesan, semakin banyak isyarat dan data yang diperlukan untuk menafsirkannya dengan benar. Misalnya, pesan sederhana yang dibuat untuk mengatur waktu dan tempat pertemuan dapat dikomunikasikan dalam email singkat, namun pesan terinci seperti tentang hasil kerja dan ekspektasi terhadap kinerja seseorang akan lebih baik dikomunikasikan melalui interaksi tatap muka.

Teori ini mencakup kerangka kerja dengan rentang ketidakjelasan dan ketidakpastian dari rendah ke tinggi. Ketidakjelasan dan ketidakpastian yang rendah menggambarkan situasi yang terdefinisi dengan baik, sedangkan ketidakjelasan dan ketidakpastian tinggi menggambarkan peristiwa ambigu yang membutuhkan klarifikasi oleh manajer. Daft dan Lengel (1984) juga menekankan bahwa kejelasan sebuah pesan dapat dikompromikan ketika terjadi komunikasi antar departemen, mengingat setiap departemen bisa jadi dilatih untuk memiliki keahlian yang berbeda atau norma komunikasi yang saling bertentangan satu sama lain.

Daft dan Lengel (1984) menyebutkan, "Semakin banyak pembelajaran yang dapat diperoleh melalui media, maka makin sempurnalah media tersebut." Kesempurnaan media adalah fungsi dari karakteristik-karakteristik berikut ini:

a. Kemampuan untuk menangani beberapa tanda-tanda informasi pada saat bersamaan. Media memiliki kemampuan yang berbeda dalam mengelola tanda informasi yang berkaitan dengan media itu sendiri, dengan demikian dipastikaan bahwa setiap media mampu untuk menangani tanda infomasi khusus yang berkaitan langsung dengan media nya.

b. Kemampuan untuk memfasilitasi umpan balik yang cepat. Media juga mempunyai kemampuan dalam hal mengelola umpan balik yang diterima dari khalayknya, oleh karena itu dalam hal memfasilitasi umpan balik-nya, media diharuskan mampu mengelola nya dengan cepat dan tepat.

c. Kemampuan untuk membangun fokus pribadi. Penyebaran informasi yang dilakukan oleh berbagai macam media jelas merupakan sebuah saluran informasi yang dianggap paling sesuai, karena penyebaran informasi tersebut merupakan hal yang berkaitan secara relevan terhadap sebuah kepentingan yang dianut.

d. Kemampuan untuk memanfaatkan bahasa alami. Penggunaan bahasa juga penting, karena dalam hal penyebaran informasi dan juga pengelolaan umpan balik, bahasa menjadi unsur penting sehingga pada akhirnya penggunaan media juga akan maksimal.

Teori kekayaan media dianggap sesuai dengan penelitian ini karena teori ini menjelaskan bahwa bagaimana media mampu mendatangkan penafsiran atas sebuah informasi berbeda antara satu media dengan media lainnya, terutama media sosial. Penulis mengkaitkan teori ini dalam penggunaan media sosial oleh Kementerian Koperasi dan UKM Republik Indonesia, untuk menggambarkan bahwasanya setiap informasi yang didapat, kemudian dikelola hendaknya dengan menggunakan media sosial yang berbeda-beda, hal ini dikarenakan dengan penggunaan media sosial yang berbeda tersebut, maka respon yang akan didapatkan dari informasi tersebut juga akan berbeda. Dengan kata lain, 
Kementerian Koperasi dan UKM Republik Indonesia harus mampu memilih dan memilah media sosial yang seharusnya digunakan dalam proses penyebaran sebuah informasi.

\section{Metode Penelitian}

Metode dalam penelitian ini menggunakan studi kasus. Selama sekitar lima belas tahun lebih, tepatnya sejak tahun 1993, seiring dengan makin populernya penelitian studi kasus, banyak pengertian penelitian studi kasus telah dikemukakan oleh para pakar tentang penelitian studi kasus. Craswell 2015 dalam (Abdul Hakim, 2017) menjelaskan bahwa suatu penelitian dapat disebut sebagai penelitian studi kasus apabila proses penelitiannya dilakukan secara mendalam dan menyeluruh terhadap kasus yang diteliti, serta mengikuti struktur studi kasus.

Dikatakan sebagai studi kasus, karena peneliti melihat adanya permasalahan yang terjadi dalam Divisi Hubungan Masyarakat Kementerian Koperasi dan UKM Republik Indonesia dalam mengelola jejaring media sosial. Subjek penelitian adalah divisi hubungan masyarakat Kementerian Koperasi dan UKM Republik Indonesia. Objek penelitan adalah strategi pengelolaan media sosial. Data primer diperoleh melalui wawancara yang dilakukan oleh beberapa narasumber. Sementara itu, data sekunder diperoleh melalui studi kepustakaan. Dari wawancara peneliti dengan Kepala Divisi Hubungan Masyarakat, Koordinator Media Sosial dan juga Admin Media Sosial Kementerian Koperasi dan UKM Republik Indonesia. Lebih jelas lagi bahwa metode penelitian ini digunakan karena adanya hubungan yang dapat dikaitkan antara metode penelitian dengan kerangka pemikiran. Hal tersebut sejalan karena penggunaan kerangka pemikiran dalam penelitian ini dimaksudkan untuk memberikan solusi atas pemecahan masalah yang dihadapi oleh Divisi Hubungan Masyarakat Kementerian Koperasi dan UKM.

\section{Hasil Penemuan dan Diskusi}

Kementerian yang resmi ada di Indonesia sejak tanggal 12 juli 1947 menjadi sebuah kementerian yang mendukung koperasi semakin berkembang bukan hanya sebagai alat perjuangan membebaskan rakyat dari penderitaan, namun menjadi alat bantu pembangunan dan perkembangan perekonomian Indonesia saat ini yang semakin pesat. Didasari pada asas kekeluargaan, koperasi telah memperbaiki taraf hidup bangsa Indonesia. Kementerian Negara Koperasi dan UKM RI adalah kementerian dalam Pemerintah Indonesia yang bertugas membantu Presiden dalam merumuskan kebijakan dan koordinasi di bidang koperasi dan usaha kecil dan menengah, serta menyelenggarakan fungsi perumusan kebijakan, koordinasi pelaksanaan, pengelolaan kekayaan, pengawasan, dan penyampaian laporan evaluasi di bidang tersebut. Disamping itu Visi dan Misi yang diemban oleh Kementerian Koperasi dan UKM Republik Indonesia secara jelas adalah untuk mendukung segala hal yang berkaitan dengan Koperasi dan Usaha Kecil Mengengah (KUMK) untuk meningkatkan pertumbuhan ekonomi yang berkualitas dan berkelanjutan. 


\section{Strategi Dalam Penanganan Tanda Informasi}

Dalam proses pengelolaan jejaring media sosial yang digunakan oleh Divisi Hubungan Masyarakat Kementerian Koperasi dan UKM Republik Indonesia, maka perlu adanya keseriusan dan juga pengembangan yang berkelanjutan dalam pengelolaan jejaring media sosial tersebut sehingga mampu memberikan informasi dengan tepat.

Dalam rangka pengembangan dan penglolaan jejaring media sosial oleh Kementerian Koperasi dan UKM Republik Indonsia melalui Divisi Hubungan Masyarakat Kementerian Koperasi dan UKM Republik Indonesia. Peneliti merumuskan sebuah usulan dalam pengelolaan jejaring media sosial untuk lebih baik lagi dengan memperhatikan beberapa hal. Terkait hal itu, ahli statistik internet dan penulis asal India, Avinash Kaushik (2011), pernah menulis bahwa fitur interaksi media sosial terbagi menjadi 3 (tiga) kategori:

1. Konversasi (conversation): Aktivitas percakapan di antara pengguna.

2. Amplifikasi (amplification): Aktivitas penyebaran atau perluasan pesan.

3. Aplaus (applause): Aktivitas respon singkat dengan ikon tertentu.

Lewat banyak artikel lain tentang komunikasi daring (online) yang merujuk pada pandangan Avinash Kaushik (2011), ketiga kategori itu bisa memandu untuk mengukur nilai engagement dalam kegiatan di media sosial. Terlebih, tiga kategori itu seolah memang jadi poros utama fitur pada layanan media sosial, seperti contoh pada tabel berikut ini:

Tabel 1. Poros Fitur Layanan Media Sosial

\begin{tabular}{lllll}
\hline Kategori & Facebook & Twitter & YouTube & Instagram \\
\hline Konversasi & Comment & Reply & Comment & Comment \\
Amplifikasi & Share & Retweet & Share & Send To \\
Aplaus & Like & Like & Like & Like \\
\hline
\end{tabular}

Pada Tabel 1 menjelaskan bagaimana aktivitas komunikasi yang dilakukan apabila menggunakan masing-masing media sosial. Tabel diatas memberikan gambaran bahwa aktivitas komunikasi yang terjadi pada masing-masing media sosial adalah berbeda. Seperti kesesuaiannya terhadap teori kekayaan media yang mengatakan bahwas media sosial memiliki karakteristik tertentu dan mempunyai jenis aktivitas yang berbeda-beda serta memiliki audiens yang berbeda pula, oleh karena itu penting untuk menggunakan media sosial yang beragam untuk mendapatkan respon yang beragam pula dari para audiens.

Tabel 1 juga secara nyata menggambarkan adanya perbedaan istilah yang digunakan oleh masing-masing media sosial dalam melakukan aktivitas komunikasi antara pemberi informasi dengan penerima informasi. Akan tetapi perbedaan ungkapan tersebut tidak menjadi suatu permasalahan yang berarti apabila dihadapkan pada kenyataan bahwa pemberi informasi dan penerima informasi sama-sama mengerti atas istilah yang digunakan. 


\section{Strategi Dalam Menangani Fasilitas Umpan Balik}

Umpan balik yang diterima atas penggunaan media sosial bisa merupakan sebuah respon positif ataupun negatif, akan tetapi dengan adanya respon tersebut baik yang positif atau negatif, maka dengan demikian dapat dipastikan bahwasanya segala bentuk penggunaan media sosial baik dalam rangka menyebarluaskan sebuah informasi atau lain hal memiliki daya tarik bagi audiens.

Kementerian Koperasi dan UKM Republik Indonesia melalui Divisi Hubungan Masyarakatnya terus berusaha memberikan respon yang baik atas semua umpan balik yang diterimanya dari audiens. Divisi Hubungan Masyarakat Kementerian Koperasi dan UKM Republik Indonesia selaku jembatan penghubung antara Institusi Pemerintah dengan public mencoba memberikan repson yang aktif, komunikatif serta responsif atas semua umpan balik yang diterimanya, dengan demikian diharapkan adanya kepuasan dari para audience atas apa yang menjadi pertanyaan mereka.

Jauh lagi, Kementerian Koperasi dan UKM Republik Indonesia telah melakukan sebuah respon yang baik, tepat dan juga benar terhadap umpan balik yang diterimanya. Admin dari Divisi Hubungan Masyarakat Kementerian Koperasi dan UKM Republik Indonesia juga telah melakukan pengelolaan jejaring media sosial dengan sangat baik, yakni menggunakan bahasa dan tutur kata yang baik atau komunikatif, sehingga pesan yang disampaikan akan diterima baik oleh para audiens nya.

Hal tersebut hendaknya tetap dipertahankan dengan baik, untuk menjaga tetap adanya umpan balik yang akan diterima oleh Kementerian Koperasi dan UKM Republik Indonesia apabila menyebarkan informasi ke audiens.

Kementerian Koperasi dan UKM Republik Indonesia melakukan kegiatan respon terhadap beredarnya informasi hoax yang mengatasnamakan karyawan dari Kementerian Koperasi dan UKM Republik Indonesia terkait dengan pinjaman modal usaha. Hal ini merupakan upaya yang dilakukan oleh Kementerian Koperasi dan UKM Republik Indonesia melalui penggunaan media sosial Instagram oleh Divis Hubungan Masyarakat dalam memfasilitasi umpan balik dari para audiens. 


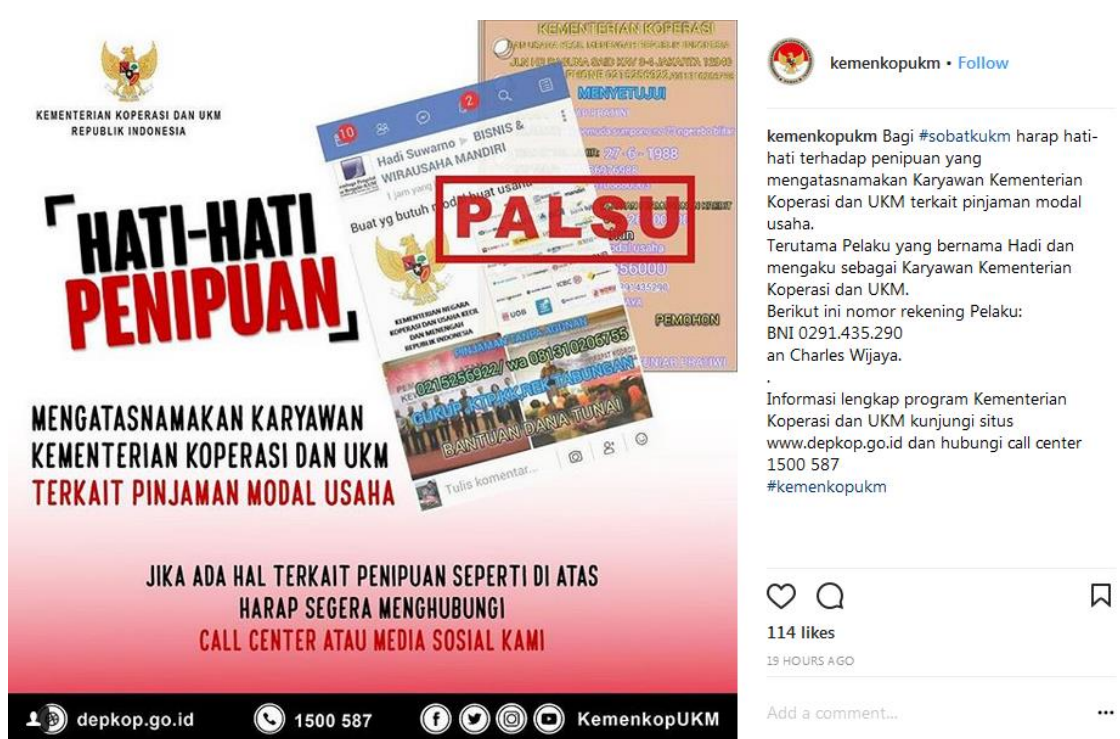

Gambar 1 : Upaya Penanggulangan Hoax Melalui Media Sosial Instagram

\section{Strategi Pengembangan Fokus}

Sebagai salah satu Kementerian yang berada di jajaran Pemerintah Indonesia, Kementerian Koperasi dan UKM Republik Indonesia merupakan Kementerian yang menjalankan tugasnya dalam bidang pengawasan Koperasi dan UKMK di seluruh Indonesia, dengan demikian sangat perlu bagi Kementerian Koperasi dan UKM Republik Indonesia mengenalkan Kementerian-nya kepada publik dengan tujuan memberikan pengetahuan bahwasanya Indonesia melalui Kementerian Koperasi dan UKM Republik Indonesia mampu memfasilitasi berbagai macam bentuk kegiatan koperasi dan UKMK yang ada di Indonesia. Salah satu cara yang digunakan Kementerian Koperasi dan UKM Republik Indonesia dalam rangka memperkenalkan Kementeria-nya kepada publik yakni dengan cara menggunakan Media Sosial.

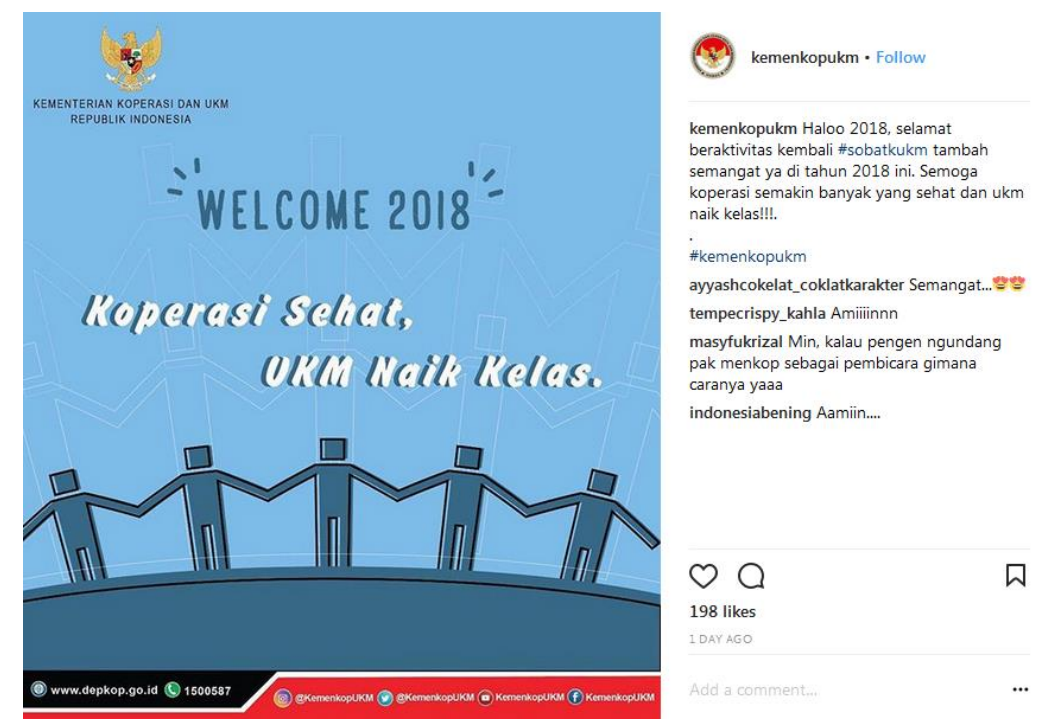

Gambar 2 : Pengenalan Melalui Post di Jejaring Media Sosial Instagram 
Hal diatas menunjukan bahwas dengan penggunaan media sosial, baik facebook, twitter, instagram atau bahkan youtube dapat pula dijadikan sebagai wadah pengembangan fokus diri dari Kementerian Koperasi dan UKM Republik Indonesia berupa pengenalan mengenai Kementerian Koperasi dan UKM Republik Indonesia itu sendiri.

Media sosial yang digunakan sebagai salah satu wadah penyebarluasan informasi dari Kementerian Koperasi dan UKM Republik Indonesia dapat pula dijadikan sebagai alat pengenalan diri kepada publik. Sejauh ini, proses pengembangan fokus diri Kementerian Koperasi dan UKM Republik Indonesia telah dengan sangat baik dilakukan dengan cara menggunakan media sosial. Dengan demikian diharapkan adanya kesadaran dan pengetahuan tentang Kementerian Koperasi dan UKM Republik Indonesia melalui pengenalan dengan media sosial.

\section{Strategi Pemanfaatan Bahasa}

Peranan penggunaan bahasa menjadi hal yang tidak kalah penting dari berbagai macam cara menciptakan komunikasi yang baik antarpihak. Bahasa menjadi tolak ukur sejauh mana satu pihak mampu mentransformasikan segala bentuk informasi yang kemudian disampaikan melalui bahasa yang baik dan benar. Penggunaan bahasa yang baik dan benar sejauh ini bisa dikatakan dengan bahasa yang komunikatif, artinya para pengguna bahasa hendaknya mampu memberi suasana yang komunikatif yang terlahir dengan penggunaan bahasa yang tidak abstrak dan mengandung kejelasan yang benar.

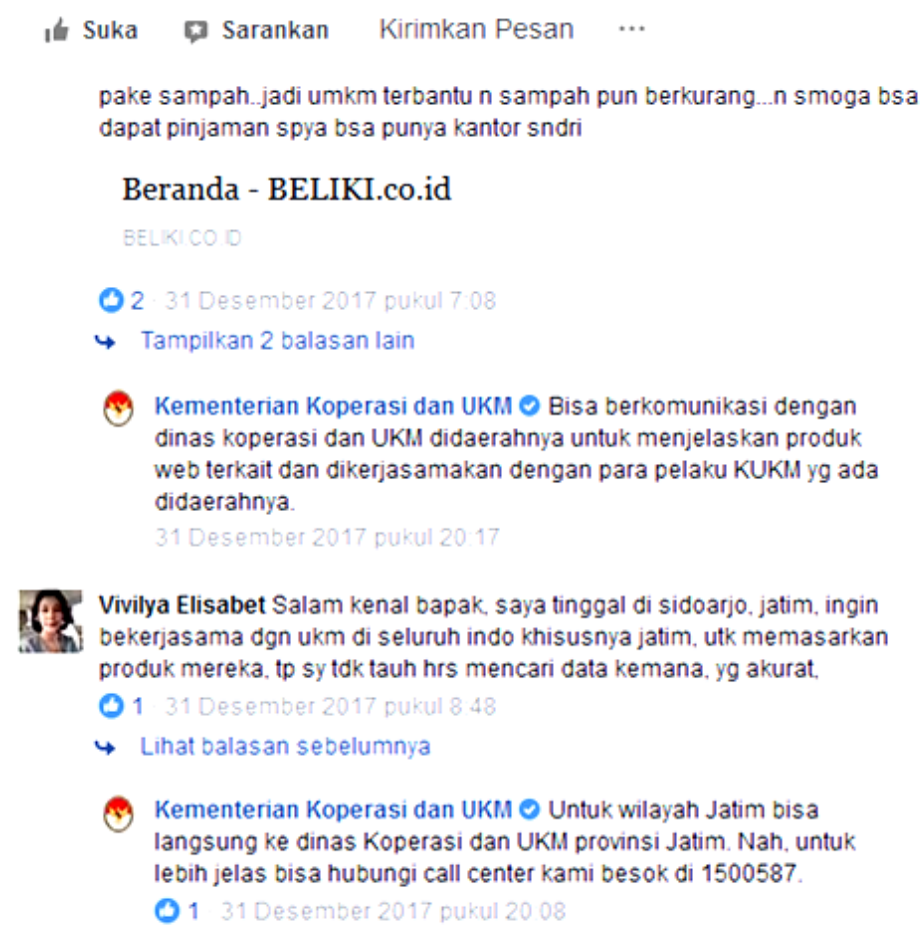

Gambar 3 : Tanggapan di Jejaring Media Sosial Facebook 
Pada gambar diatas memberikan informasi bahwa Kementerian Koperasi dan UKM Republik Indonesia melakukan aktivitas komunikasi yang baik, artinya kementrian berusaha untuk memberikan tanggapan atas respon yang diberikan oleh publiknya dengan mencari solusi atau jawaban atas apa yang dipertanyakan dengan menggunakan bahasa yang baik, benar dan juga informatif, dengan demikian publik akan merasa terbantu atas apa yang telah dijelaskan oleh Kementerian Koperasi dan UKM Republik Indonesia.

Sejauh ini, Kementerian Koperasi dan UKM Republik Indonesia telah melakukan aktivitas komunikasi dua arah yang sudah baik, akan tetapi diharapkan nantinya akan menjadi lebih baik lagi dalam menyampaikan ataupun juga memberikan tanggapan atas apa yang menjadi sebuah pertanyaan yang diajukan publik kepada Kementerian Koperasi dan UKM Republik Indonesia.

\section{Pembahasan}

Kementerian Koperasi dan UKM Republik Indonesia melalui Divisi Hubungan Masyarakat mencoba untuk menggunakan media sosial sebagai suatu wadah penyampaian dan juga penyebarluasan informasi kepada publik. Hal ini ditempuh sebagai jawaban atas perkembangan teknologi dan informasi pada era ini yang mengharuskan adanya penggunaan dan pengoptimalan penggunaan media sosial dalam kaitannya dengan keefektivitasannya dalam mengolah informasi.

Penggunaan media sosial menjadi hal yang terlihat penting, karena dengan adanya penggunaan media sosial dalam mendukung kehidupan Kementerian Koperasi dan UKM Republik Indonesia menjadikan Kementerian Koperasi dan UKM Republik Indonesia mampu untuk dikenal oleh masyarakat yang lebih luas lagi terutama para pengguna media sosial, dengan demikan maka Kementerian Koperasi dan UKM Republik Indonesia akan mendapatkan perhatian yang cukup baik dari publik.

Dalam menggunakan media sosial yang berkaitan dengan penyebarluasan informasi dan juga pengelolaan informasi maka hal tersebut selaras dengan salah satu teori media sosial yakni Teori Kekayaan Media atau Media Richness Theory. Dalam teori kekayaan media dikatakan bahwasanya dalam penggunaan media sosial maka akan ditemukan berbagai macam perbedaan yang mencolok, yang artinya bahwa tidak semua media sosial memiliki kesamaan dalam kegiatan penggunaannya. Perbedaan yang bisa diketahui adalah dalam penggunaan media sosial akan didapatkan respon dan juga aktivitas yang berbeda satu sama lain, yang artinya penggunaan media sosial perlu dikembangkan lagi untuk mendapatkan respon yang beragam agar proses pengelolaan dan penyebarluasan informasi dapat dilakukan dengan efektif. Teori kekayaan media meliputi empat aspek pembahasan yakni; bagaimana dengan menggunakan media sosial Kementerian Koperasi dan UKM Republik Indonesia mampu menangani tanda informasi, umpan balik, pengembangan fokus dan juga pemanfaatan bahasa.

Penanganan tanda informasi dalam penggunaan media sosial oleh Divisi Hubungan Masyarakat Kementerian Koperasi dan UKM Republik Indonesia menjadi hal yang harus diperhatikan dengan baik. Sejauh ini, Divisi Hubungan Masyarakat Kementerian Koperasi dan UKM Republik Indonesia telah mampu 
mengelola tanda informasi yang diterimanya dari media sosial yang dimiliki. Dalam menggunakan berbagai macam media sosial oleh Divisi Hubungan Masyarakat Kementerian Koperasi dan UKM Republik Indonesia maka akan didapatkan tanda informasi yang berbeda-beda tergantung media sosial yang digunakan. Divisi Hubungan Masyarakat Kementerian Koperasi dan UKM Republik Indonesia melakukan kegiatan penanganan tanda informasi yang cukup responsif, artinya setiap ada tanda informasi yang didapatkan dari penggunaan media sosial baik berupa tanda informasi "komentar" atau "menyukai", maka akan mendapatkan respon balasan yang cukup responsif dari Divisi Hubungan Masyarakat Kementerian Koperasi dan UKM Republik Indonesia melalui admin pengelola media sosial tersebut. Adanya pengelolaan tanda informasi yang diberikan publik melalui media sosial yang dikelola oleh admin Divisi Hubungan Masyarakat Kementrian Koperasi dan UKM Republik Indonesia maka publik dan juga Kementerian Koperasi dan UKM Republik Indonesia telah sama-sama melakukan kegiatan pengelolaan dan juga penyebarluasan informasi melalui media sosial sesuai dengan perkembangan zaman yang ada pada saat ini.

Jauh lagi mengenai admin media sosial Divisi Hubungan Masyarakat Kementerian Koperasi dan UKM Republik Indonesia dalam mengelola umpan balik yang diterima dari publik adalah dengan selalu menjadi admin media sosial yang cepat tanggap atas suatu permasalahan yang dialami oleh publik berkaitan dengan adanya informasi yang disebarluaskan oleh Kementerian Koperasi dan UKM Republik Indonesia. Admin media sosial Divisi Hubungan Masyarakat Kementerian Koperasi dan UKM Republik Indonesia berusaha memberikan penjelasan secara mendetail atas semua respon yang diberikan oleh publik baik respon yang sifatnya positif ataupun negatif. Hal tersebut dilakukan dengan tujuan agar publik dapat mendapatkan yang sebenarnya mereka butuhkan dengan baik dan detail.

Melalui penggunaan media sosial oleh Kementerian Koperasi dan UKM Republik Indonesia maka Kementerian Koperasi dan UKM Republik Indonesia dapat sekaligus memperkenalkan kementeriannya kepada publik luas, hal ini ditujukan sebagai wujud pengenalan dan juga memberikan kesadaran kepada publik akan keeksistensian dari sebuah kementerian dibawah pemerintahan Indonesia yakni Kementerian Koperasi dan UKM Republik Indonesia yang memiliki tugas dan wewenang untuk mengatur seluruh kegiatan kehidupan koperasi dan UKM yang ada diseluruh wilayah di Indonesia.

Penggunaan bahasa juga sangat penting dalam pengelolaan media sosial, dengan dasar penggunaan bahasa yang baik, benar dan juga efektif maka penyebarluasan informasi dengan menggunakan media sosial oleh Kementerian Koperasi dan UKM Republik Indonesia akan mendapatkan hasil yang optimal. Penggunaan bahasa yang baik juga menjadi tolak ukur sejauh mana admin pengelola media sosial mampu menjangkau publiknya secara luas dengan menggunakan bahasa yang mampu dipahami oleh kalangan luas. Sehingga informasi dapat disampaikan dengan baik kepada publik. 


\section{Simpulan}

Divisi Hubungan Masyarakat Kementerian Koperasi dan UKM Republik Indonesia pada proses penyebarluasan informasi yang dimiliki menggunakan beragam media sosial, antara lain : facebook, twitter, instagram dan juga youtube. Sejauh ini, penggunaan media sosial oleh Divisi Hubungan Masyarakat Kementerian Koperasi dan UKM Republik Indonesia menjadi penting karena melihat ketertarikan dari publik atas informasi yang disebarluaskan melalui media sosial. Dari keempat media sosial yang digunakan oleh Divisi Hubungan Masyarakat Kementerian Koperasi dan UKM Republik Indonesia, satu di antaranya masih dalam proses pengembangan pengelolaan. Media sosial yang dimaksud adalah youtube. Penggunaan youtube masih minim karena untuk mengelola jejaring sosial ini diperlukan persiapan yang cukup matang. Akan tetapi nantinya, penggunaan youtube akan dioptimalkan untuk pengembangan wadah penyebarluasan informasi oleh Kementerian Koperasi dan UKM Republik Indonesia melalui Divisi Hubungan Masyarakat Kementerian Koperasi dan UKM Republik Indonesia.

Di lain sisi, penggunaan media sosial sebagai wadah penyebarluasan informasi juga menjadi wadah untuk mendapatkan respon yang bersifat dua arah, maksudnya baik penyebar informasi atau pihak yang mendapatkan informasi tersebut mampu melakukan sebuah hubungan komunikasi melalui kolom komentar yang tersedia dalam media sosial tersebut. Lebih jauh, penggunaan media sosial dalam menyebarkan informasi memiliki respon yang beragam, mulai dari respon positif hingga respon yang bersifat negatif. Kementerian Koperasi dan UKM Republik Indonesia melalui Divisi Hubungan Masyarakat mengelola respon yang diterima dengan sangat baik, mereka melakukan pendekatan responsif dengan selalu menjadi pendengar dan juga pemberi jawaban pasti yang sangat detail sehingga mengurangi kesalahpahaman yang timbul, hal ini juga dilakukan untuk memberikan klarifikasi pada komentar yang bersifat negatif.

Dalam komunikasi responsif yang dilakukan oleh Kementerian Koperasi dan UKM Republik Indonesia dalam memberikan klarifikasi dan juga penjelasan mengenai sebuah komentar baik komentar positif dan juga negatif, Divisi Hubungan Masyarakat Kementerian Koperasi dan UKM Republik Indonesia menggunakan bahasa yang dapat dimengerti oleh semua orang, sehingga jawaban yang diberikan dapat dipahami publik nya dengan sangat baik. Hal ini juga ditujukan untuk menghindari kesalahpahaman lagi terhadap klarifikasi yang diberikan.

Media sosial yang digunakan oleh Divisi Hubungan Masyarakat Kementerian Koperasi dan UKM Republik Indonesia juga menjadi sebuah wadah yang tidak hanya untuk penyebarluasan informasi saja, melainkan juga digunakan sebagai wadah pengenalan Kementerian kepada publik. Hal ini dilakukan dengan memberikan gambaran jelas yang hadir bersamaan penyebaran informasi mengenai apa itu Kementerian Koperasi dan UKM Republik Indonesia dan bagaimana tugas serta fungsi yang diemban oleh Kementerian Koperasi dan UKM Republik Indonesia, dengan demikian publik dapat mengetahui lebih jauh lagi mengenai Kementerian Koperasi dan UKM Republik Indonesia. 


\section{Ucapan Terima Kasih}

Peneliti mengucapkan terima kasih kepada segenap Staf Hubungan Masyarakat dan Advokasi Hukum Kementerian Koperasi dan Usaha Kecil dan Menengah Republik Indonesia, Bapak Darmono selaku Kepala Bagian Humas dan Advokasi Hukum Kementerian Koperasi dan Usaha Kecil dan Menengah Republik Indonesia,Bapak Maulana Selaku Kepala Divisi Hubungan Masyarakat Kementerian Koperasi dan UKM Republik Indonesia Bidang Advokasi dan Hukum, Bapak Muhammad. Ali Selaku Koordinator Media Sosial Kementerian Koperasi dan UKM Republik Indonesia, dan Ibu Dwitya Suci selaku Staf Publikasi dan Dokumentasi yang mengelola media sosial atas bantuannya kemudahan mengumpulkan data dalam melakukan penelitian ini.

\section{Daftar Pustaka}

Carlina, Gladys., \& Paramita, Sinta. (2017). PR Crisis Melalui Media Sosial. Jurnal Komunikasi, Vol. 9, No. 1, Juli 2017, Hal 81 - 86. https://journal.untar.ac.id/index.php/komunikasi/article/view/211/647

Daft, R. and R. Lengel. (1984). Information Richness : A New Approach To Managerial Behaviour and Organization Design. Research In Organizational Behaviour, Vol.6 : 191 - 233.

Hakim, Abdul. (2017). Metodologi Penelitian Penelitian Kualitatif, Tindakan Kelas \& Studi Kasus. Sukabumi : CV. Jejak.

Herlanti, Yanti. (2004). Pemanfaatan Media Sosial Pada Pembelajaran Berbasis Isu Sosio saintifik Untuk Mengembangkan Keterampilan Berargumentasi Dan Literasi Sains. Bandung : Program Studi Pendidikan Ilmu Pengetahuan Alam Sekolah Pascasarjana Universitas Pendidikan Bandung.

Kaushik, Avinash. (2011). Best Social Media Metrics Conversation, Amplification, Applause, Economic Value”. https://www.kaushik.net/avinash/best-social-media-metrics-conversationamplification-applause-economic-value/. Diakses pada 20 Desember 2018 Pukul 19:32 WIB.

Kustiny, Henny. (2017). Communication Skill. Sleman : CV. Budi Utama.

Kementerian Komunikasi dan Informatika Republik Indonesia. (2017). Pemerintah Daerah Harus Aktif Dalam Menggunakan Media Sosial. Diakses pada 26 Oktober 2017 pada Pukul 18:35 WIB. https://kominfo.go.id/content/detail/9712/pemerintah-daerah-harus-aktifgunakan-media-sosial/0/berita_satker.

Nova, Firsan. (2009). Crisis Public Relations : Bagaimana PR Menangani Krisis Perusahaan. Jakarta : PT Gramedia Widiasarana Indonesia.

Prayudi, SIP. MA. Ph.D. (2012). Public Relations Stratejik. Yogyakarta : Komunikasi UPN Press.

Ruslan, Rosady. (2016). Manajemen Public Relations \& Media Komunikasi, Konsepsi, dan Aplikasi. Jakarta : PT. Raja Grafindo Persada. 
Seitel, Fraser P. (2001). The Practice of Public Relations, $8^{\text {th }}$ ed. New Jersey: Prentice Hall.

Stelzner, M.A. (2016). Social Media Marketing Industry Report : How To Marketers Are Using Social Media To Grow Their Businesses. http://www.socialmediaexaminer.com/social-media-marketing-industryreport-2016/.

Suprawoto. (2018). Government Public Relations : Perkembangan dan Praktik di Indonesia. Jakarta : Prenadamedia Grup.

Zarella, D. (2010). The Social Media Marketing Book. Jakarta : PT. Serambi Ilmu Semesta Anggota IKAPI. 